Ksenija Šulović, Dragana Drobnjak

UDK 811.163.41'373.7:336.7

Filozofski fakultet

811.133.1'373.7:336.7

Univerziteta u Novom Sadu

811.134.2’373.7:336.7

Originalan naučni rad

\title{
NOVAC U SRPSKOJ, FRANCUSKOJ I ŠPANSKOJ FRAZEOLOGIJI ${ }^{1}$
}

Predmet ovog rada čine srpske, francuske i španske frazeološke jedinice sa komponentom srp. novac, pare / fr. argent / šp. dinero, kao i sa drugim komponentama bliske semantike. Cilj rada je da kognitivno-konceptualnom analizom odabrane frazeme svrstamo u konceptualna polja shodno njihovoj pozadinskoj slici, kao i da utvrdimo (ne)istovetnost leksičke i semantičke strukture frazeoloških jedinica u tri posmatrana jezika.

Ključne reči: novac, frazem, srpski, francuski, španski.

\section{UVOD}

Predmet ovog rada čine srpske, francuske i španske frazeološke jedinice koje se odnose na semantičko polje 'novac', kako one koje sadrže komponentu srp. novac, pare / fr. argent / šp. dinero, tako i one koje pomenutu komponentu ne sadrže, ali semantikom upućuju na posmatrano polje. Cilj rada je da kognitivnokonceptualnom analizom odabrane frazeme svrstamo u konceptualna polja shodno njihovoj pozadinskoj slici, odnosno tome da li upućuju na (ne)posedovanje novca, na čovekov odnos prema novcu, na novčanu vrednost stvari ili na neke druge pojmove. Pored toga, ustanovićemo (ne)istovetnost leksičke i semantičke strukture frazeoloških jedinica u srpskom, francuskom i španskom jeziku. Osvrnućemo se i na pojmovne metafore kako bismo uočili način na koji tri lingvokulturalne zajednice konceptualizuju novac.

Korpus za ovo istraživanje ekscerpirale smo iz opštih i frazeoloških rečnika triju jezika, raznovrsnih dnevnih i nedeljnih novina, elektronskih medija, bez pretenzije da u analizu uvrstimo sve postojeće jezičke realizacije koje upućuju na novac.

Mada posmatrani jezici pripadaju indoevropskoj porodici, pripadnost različitim jezičkim grupama, kao i izloženost neistovetnim kulturološkim, istorijskim i

\footnotetext{
Dragana Drobnjak dashayuyu@yahoo.fr, Ksenija Šulović ksenijasulovic@gmail.com,

Rad je urađen u okviru projekta MNTR br. 178002 Jezici i kulture u vremenu i prostoru.
} 
drugim činiocima, uticale su na stvaranje osobenih sociolingvističkih miljea. Stoga je sasvim očekivano i razlikovanje u frazeološkom izražavanju u srpskom, francuskom i španskom jeziku.

\section{NOVAC I KONCEPTUALNA POLJA}

\subsection{Definicija novca}

Prema Rečniku SANU (knj. 15: 731-732) novac je:

1. a. naročito izrađen metal ili papir određenog oblika i veličine utvrđene vrednosti, koji izdaje država, a služi kao opšte sredstvo razmene dobara, odn. kao priznato sredstvo plaćanja pri razmeni svih proizvoda ljudskog roda; uopšte sredstvo plaćanja. b. novčanica u metalu. v. zast. novčana jedinica različite (uglavnom osnovne) vrednosti, u razno doba kod pojedinih država. g. ist. petina groša u Srbiji do 1918. godine. 2. imovina, bogatstvo; kapital.

U srpski deo korpusa uvrstile smo i frazeološke jedinice sa komponentama para/pare i dinar koje semantički poistovećujemo sa komponentom novac shodno definicijama iz RMS. Tako je para (knj. 4: 329): 1. novčana jedinica ravna 1/100 dinara, sitan novac te vrednosti. 2. (obično mn.) uopšte novac, novčana sredstva, a dinar (knj. 1: 684): 1. osnovna jedinica jugoslovenskog novca. 2. novac uopšte.

Prema francuskom rečniku TLF (knj. 3: 467-468), prvo značenje lekseme argent jeste 'srebro', potom 'predmet od srebra' i 'srebrni novac', te 'novac' i 'imovina, bogatstvo'.

Značenja lekseme dinero koje navodi španski rečnik RAE (knj. 1: 753) istovetna su značenjima srpske imenice (osim pod 1. v. i g.).

$\mathrm{U}$ većini primera na mestu leksema srp. novac/pare/dinar, fr. argent, šp. dinero mogu se koristiti i sinonimske lekseme koje pripadaju različitim registrima (npr. srp. lova, kinta, banka / fr. pognon, fric, blé, oseille, beurre, pèze, flouze / šp. duro, lana, pela, pasta, plata, trigo, cuartos, guita, efectivo, parné), ali ih u radu nećemo posebno navoditi.

2.2. 2.2. Novac i pojmovne metafore

$\mathrm{S}$ jedne strane, novac je prototipični trodimenzionalni predmet budući da je opipljiv (čvrst), perceptivno odvojiv od okoline (ima oblik na osnovu kojeg se može prepoznati) i funkcionalan (prenosiv je i može se njime rukovati). S druge strane, usled sve prisutnijeg virtuelnog ,cirkulisanja“, novac se ne percipira čulima (ne vidi se i nije opipljiv), već je iskazan ciframa (Šulović, Drobnjak 2015). U radu se nećemo baviti razlučivanjem granice između opipljivog i neopipljivog novca, budući da ju je često nemoguće sa preciznošću odrediti, a svakako nije presudna za naš rad.

Novac kao prototipični trodimenzionalni PREDMET vrednuje se u skladu sa estetskim kriterijumima (npr. lepe pare), odnosno kvalifikuje (npr. sitne, velike, krupne, ogromne pare). NOVAC se poima kao LEPLJVI PREDMET: srp. novac se lepi 
za nas / fr. - / šp. -; LEPLJIVA PODLOGA ZA SEDENJE/LEŽANJE/SPAVANJE: srp. sedeti, ležati, spavati na novcu / fr. - / šp. -; KLJUČ: srp. novac otvara sva vrata / fr. l'argent ouvre toutes les portes / ̌̌p. el dinero abre mil puertas.

$\mathrm{S}$ druge strane, prototipična MATERIJA nema granice, a time ni oblik, može da teče i da se sipa, vidljiva je, opipljiva i pruža otpor kretanju, potencijalno se beskonačno prostire, ali je po izgledu i osobinama ista u svim delovima (Klikovac 2000). Tečnost je jedna od prototipičnih MATERIJA, te generišemo metaforu NOVAC JE TEČNOST: srp. novac kaplje sa svih strana / fr. l'argent dégouline de partout / šp. el dinero gotea por todas partes; srp. priliv novca / fr. afflux de l'argent / šp. afluencia del dinero; srp. novac mu curi kroz prste / fr. argent lui coule des doigts / šp. el dinero se le escurre entre los dedos.

Iz ove metafore proističe sledeći pojmovni lanac: NOVAC JE (NE)POKRETNA VODENA MASA: srp. plivati u novcu / fr. nager dans l'argent / šp. estar nadando en dinero; srp. daviti se u novcu / fr. - / šp. -; srp. - / fr. l'argent coule à flots ('novac teče u talasima') ${ }^{2}$ / šp. -; srp. - / fr. - / šp. el río de dinero se secó ('reka novca je presušila'); NOVAC JE KIŠA/PLJUSAK: srp. novac pljušti sa svih strana / fr. il pleut de l'argent / šp. llueve dinero; NOVAC JE TEČNOST KOJA IMA IZVOR: srp. izvori novca su presušili / fr. les sources de l'argent se sont asséchées / šp. la fuente de dinero se secó; NOVAC JE ALKOHOLNO PIĆE: srp. opijenost novcem / fr. ivresse de l'argent / šp. embriaguez de dinero; srp. propiti novac / fr. - / šp. - .

Manje čvrsti članovi kategorije MATERIJE (npr. prašina, pesak) mogu da se sipaju, ali ne i da teku, za razliku od onih potpuno čvrstih (npr. drvo, mermer, kamen) koji nemaju tu mogućnost. U našem korpusu uočavamo nekoliko takvih primera: NOVAC JE HRANA: srp. glad za novcem / fr. faim pour l'argent / šp. hambriento por dinero; srp. proždirati novac / fr. engloutir, dévorer de l'argent / šp. devorar el dinero; NOVAC JE MATERIJA PODLOŽNA TRULJENJU: srp. truli novac / fr. argent pourri / šp. dinero podrido; NOVAC JE MATERIJA KOJA MOŽE DA SE TOPI: srp. novac mu se topi / fr. l'argent lui fond dans les mains / šp. el dinero se le ha fundido.

NOVAC se često konceptualizuje kao BIĆE: srp. novac nikad ne spava / fr. l'argent ne dort jamais / šp. dinero nunca duerme; srp. mrtav novac / fr. argent mort / šp. dinero muerto.

Čovek često personifikuje predmete i pojave koji ga okružuju. Otuda i metafora NOVAC JE ČOVEK: srp. jezik novca / fr. le langage de l'argent / šp. el lenguaje del dinero, koja se potom preliva u sledeći pojmovni lanac: NOVAC JE ROBOVLASNIK: srp. biti rob novca / fr. être esclave de l'argent / šp. esclavo del dinero; NOVAC JE VLADAR: srp. novac vlada svetom / fr. l'argent gouverne le monde / šp. el dinero gobierna al mundo; NOVAC JE ZAROBLJENIK: srp. zarobljen mu je novac u banci / fr.

\footnotetext{
Kod metafora gde ne nalazimo primer u srpskom jeziku, u zagradi navodimo doslovan prevod za francuski i španski, a ne frazeološko značenje.
} 
- / šp. -; NOVAC JE RADNIK: srp. novac radi za mene / fr. - / šp. el dinero trabaja para mi. ${ }^{3}$

\subsection{Frazemi i konceptualna polja}

Prema Burgeru (1982) frazem predstavlja spoj dve ili više reči (pri čemu uslov ne predstavlja punoznačnost barem jedne od njih) koji odlikuje čvrsta struktura, bez obzira na njenu (ne)idiomatičnost ${ }^{4}$.

Rajna Dragićević pod frazemom podrazumeva ustaljenu jezičku jedinicu sastavljenu od dveju ili više reči koje ne zadržavaju svoja značenja, već celokupan sklop ima jedinstveno značenje i gramatički i semantički je nepromenljiv (Dragićević 2010).

U kognitivnoj lingvistici frazemi se poimaju kao psiholingvističke jedinice unutar 'mentalnog leksikona' koji predstavlja mrežu pojmovnih jedinica pridruženih jednom ili više konceptualnih polja obrazovanih na osnovu izvanjezičkih kriterijuma, odnosno čovekovog znanja o svetu. Konceptualnosemantičko umreženje frazema moguće je ostvariti metodom semantičke dekompozicije tako što se frazemima pridružuju odgovarajući deskriptori (svojstva koja predstavljaju odnose sličnosti). Dobrovoljski (prema Zybatov 1997: 582) predlaže 'tehniku grozdova' u okviru koje frazeme unutar jednog grozda povezuje semantička sličnost na intuitivnom nivou. Tako svaki konceptualni grozd predstavlja skup deskriptora čineći 'takson'. Pridruživanje deskriptora frazemima zavisi često od konteksta, te pojedinim frazemima koje krasi više značenja samim tim može da se pridruži više deskriptora. Isto tako, frazeme unutar jednog taksona povezuje istovetno relevantno obeležje stapajući ih u značenjsku celinu, a da oni pritom ne moraju da dele nijedan deskriptor.

Prateći ovakav leksikografski postupak, frazeme iz našeg korpusa grupisale smo u tri konceptualna polja, odnosno grozda: 1) '(ne)posedovanje novca', 2) 'čovekov odnos prema novcu' i 3) 'novčana vrednost stvari'. U posebne grupe svrstale smo frazeme koji upućuju na druge aspekte novca i one koji se na novac ne odnose uprkos prisustvu odabranih konstituenata.

U našoj analizi, pod leksičkim poklapanjem podrazumevamo prisustvo istih ili sličnih komponenti u frazemima tri jezika, a pod semantičkim istovetni koncept koji oni izražavaju. Frazeme istog ili sličnog značenja, ali neistovetne leksičke strukture smatraćemo korespondentima, ne i ekvivalentima. Navodićemo najpre poklapanje u tri jezika, potom u dva, te primere koji postoje samo u jednom jeziku.

\footnotetext{
Više o pojmovnim metaforama u minimalnim okruženjima leksema srp. novac, fr. argent, šp. dinero u: Šulović, Drobnjak 2015.

4 Prema Burgeru (2003: 31-32) frazem je idiomatičan ukoliko njegovo značenje ne može da se izvede iz doslovnog značenja komponenata, "poluidiomatičan” ukoliko je unutar frazema jedna komponenta sačuvala značenje, a "neidiomatičan" kada semantička razlika između frazeološkog i nefrazeološkog značenja ne postoji ili je minimalna.
} 


\subsubsection{Konceptualno polje '(ne)posedovanje novca'}

Ovo konceptualno polje grade frazemi čija semantika ukazuje na (ne) posedovanje novca, odnosno na imovinsko stanje, $i$ čine je tri podgrupe. U prvoj pronalazimo frazeme koji označavaju posedovanje i raspolaganje velikom količinom novca, u drugoj one koji ističu posedovanje skromne količine novca, a u trećoj one koji govore o neimanju novca. Konceptualno polje 'novac' time se prepliće sa konceptualnim poljima 'bogatstvo' i 'siromaštvo'. Siromaštvo je obično negativno konotirano, dok je bogatstvo obojeno društvenom prihvatljivošću i poželjnošću, mada i ono, zavisno od konteksta i govornika, može da nosi negativnu notu. Kod frazema nejasne semantike, navešćemo pozadinsku sliku.

a) 'posedovanje velike količine novca':

srp. plivati u novcu / fr. nager dans l'argent / šp. estar nadando en dinero srp. ne zna šta će s novcem, parama / fr. il ne sait que faire de son argent / šp. no sabe qué hacer con tanto dinero

srp. biti dubokog džepa / fr. avoir une poche profonde / šp. tener bolsillo profundo

srp. imati pune džepove (para) / fr. avoir les poches pleines (d'argent) / šp. tener bolsillos llenos (de dinero)

srp. valjati se u novcu / fr. se vautrer dans l'argent / šp. revolcarse en dinero

srp. imati brdo ara $^{5}$ / fr. avoir une montagne d'argent / šp. tener una montaña de dinero

srp. živi kao princ / fr. il vit comme un prince / šp. él vive como un príncipe 6

srp. daviti se u novcu / fr. - / šp. ahogarse en dinero

srp. - / fr. nager dans l'opulence ('plivati u izobilju') / šp. nadando en riqueza ('plivajući u bogatstvu')

srp. imati novca, para kao pleve / fr. - / šp. -

srp. imati novca, para kao blata / fr. - / šp. -

srp. biti pun kao brod / fr. - / šp. -

srp. imati love do krova / fr. - / šp. -

srp. biti debelog džepa / fr. - / šp. -

srp. ležati, sedeti, spavati na novcu, parama / fr. - / šp. -

srp. biti pun para kao pas buva / fr. - / šp. -

srp. - / fr. avoir un argent fou ('imati novac lud') / šp. -

srp. - / fr. remuer l'argent à la pelle ('pomerati novac lopatom') / šp. -

srp. - / fr. être plein aux as ('biti pun kečeva') / šp. -

$5 \quad$ Brdo para može i da se potroši, izgubi, plati, te samim tim ovaj frazem može da se svrsta i u druga konceptualna polja.

6 Navedeni frazem postoji u više varijanti u tri jezika: srp. živeti kao kralj, car, paša, bubreg u loju, fr. vivre comme un roi, nabab, pacha, maharaja, un coq en pâte ('živeti kao kralj, nabab, paša, maharadža, petao u testu'), šp. vivir como un cura, obispo, pachá, marajá, rey, emperador, general ('živeti kao pop, biskup, paša, maharadža, kralj, car, general'). 
srp. - / fr. rouler sur l'or ('valjati se na zlatu') / šp. -

srp. - / fr. être cousu d'or ('biti prošiven zlatom') / šp. hacerse alguien de oro ('sačinjen neko od zlata')

srp. - / fr. avoir la bourse pleine ('imati punu kesu') / šp. -

srp. - / fr. avoir la bourse ronde ('imati okruglu kesu') / šp. -

srp. - / fr. - / šp. tener dinero como para parar un tren ('imati para kao za zaustavljanje voza')

srp. - / fr. - / šp. vivir a cuerpo de rey ('živeti u telu kralja')

srp. - / fr. - / šp. tener el cuerno de la abundancia ${ }^{7}$ ('imati rogove obilja')

U pojedinim frazemima pronalazimo ličnosti iz mitologije, istorije, svakodnevice kao sinonim za izuzetno bogatstvo: feller

srp. živeti kao Rokfeler / fr. vivre comme Rockefeller / šp. vivir como RockeCreso $^{8}$

srp. biti bogat kao Krez / fr. être riche comme Crésus / šp. ser rico como

srp. blago cara Radovana / fr. - / šp. -

U ovu grupu uvrstile smo i frazeme koji upućuju na sticanje velike količine novca koji se umnožava:

srp. novac pljušti sa svih strana / fr. il pleut de l'argent / šp. llueve dinero

srp. okretati, obrtati pare / fr. - / šp. -

srp. mlatiti pare, namlatiti se para / fr. - / šp. -

srp. - / fr. toucher le pactole ('dotaći, doticati bogatstvo') / šp. -

srp. - / fr. brasser de l'argent ('mešati novac') / šp. -

srp. - / fr. faire des affaires d'or ('(na)praviti zlatne poslove') / šp. -

srp. - / fr. - / šp. tocar el gordo ('dotaći debelog')

srp. - / fr. - / šp. ganar dinero a punta de pala ('zarađivati novac do vrha drške lopate' $)^{9}$

srp. - / fr. - / šp. ganar dinero a espuertas ('zarađivati novac u kotaricama') ${ }^{10}$ srp. - / fr. - / šp. ganar dinero a manta ('zarađivati novac u ćebetu') ${ }^{11}$

Sledeći frazemi ističu lakoću sticanja velike količine novca bez ulaganja napora, često zahvaljujući tuđem radu i zalaganju ili nekom drugom izvoru:

srp. pare padaju sa neba / fr. l'argent tombe du ciel / šp. dinero cae del cielo srp. pronaći rudnik zlata / fr. trouver une mine d'or / šp. srp. dići novac na brzinu / fr. - / šp. -

\footnotetext{
Prema mitologiji, rog izobilja je zapravo čaša u obliku roga puna voća i cveća koja se prinosila Tihi, grčko-rimskoj boginji izobilja.

8 U pozadinskoj slici pronalazimo lidijskog cara Kreza, najbogatijeg vladara u istoriji.

$9 \quad$ Pozadinska slika upućuje na zarađivanje velike količine novca koja se tovari lopatom.

10 U pozadinskoj slici je velika količina novca koja se prenosi u kotaricama.

11 Pozadinska slika upućuje na zarađivanje velike količine novca koja se prenosi u ćebetu.
} 
srp. - / fr. - / šp. hacer el agosto ${ }^{12}$ ('napraviti avgust')

srp. - / fr. - / šp. encontrar una mina ('pronaći rudnik')

Srpski frazem zgrnuti, zgrtati novac, pare preko noći pokazuje da veliki novac može da se zaradi za vrlo kratko vreme. Frazemi srp. napuniti džep(ove) / fr. emplir sa poche, se remplir les poches / šp. llenar los bolsillos nose i sem 'nezakonito, nepošteno zarađivanje velike količine novca', dok se frazem srp. - / fr. l'assiette au beurre ('tanjir sa puterom') / šp. - odnosi na nelegalan izvor novca.

S druge strane, pojedini frazemi ukazuju na teško sticanje novca, sopstvenim trudom i poštenim radom:

srp. - / fr. gagner son pain à la sueur de son front ('zarađivati svoj hleb znojem svog čela') / šp. ganar el pan con el sudor de la frente ('zarađivati hleb znojem čela')

srp. znojem zarađen novac / fr. - / šp. -

srp. krvav novac / fr. - / šp. -

Zanimljiv je španski frazem escupir sangre en bacín de oro ('pljuvati krv u zlatni vrč') koji označava čoveka koji poseduje veliko bogatstvo, ali nema sreće da u njemu uživa.

b) 'posedovanje skromne količine novca':

srp. stezati kaiš / fr. se serrer la ceinture / šp. apretarse el cinturón srp. sastavljati kraj s krajem / fr. joindre les deux bouts / šp. srp. biti tankog džepa / fr. - / šp. tener bolsillo flaco

srp. krpiti kraj s krajem / fr. - / šp. -

srp. (pre)živeti od prvog do prvog / fr. - / šp. -

srp. biti plitkog džepa / fr. - / šp. -

srp. - / fr. avoir la bourse plate ('imati ravnu, plitku kesu') / šp. -

srp. - / fr. nouer les deux bouts ('vezati u čvor dva kraja') / šp. -

srp. - / fr. être réduit à la portion congrue ('biti sveden na odgovarajuću porciju') / šp. -

srp. - / fr. - / šp. vivir a media ración ('živeti na pola porcije’)

c) 'neposedovanje novca', 'siromaštvo':

srp. siromašan kao crkveni miš ${ }^{13}$ / fr. pauvre comme un rat d'église / šp. pobre como un ratón de iglesia

srp. imati novca, para kao žaba dlaka ${ }^{14}$ / fr. être chargé d'argent comme un crapaud de plumes / šp. cargado como un sapo de plumas

\footnotetext{
12 U pozadinskoj slici pronalazimo zapravo letnju stočnu pijacu koja se tokom Srednjeg veka organizovala na čitavom Iberijskom poluostrvu, naročito u Kastilji. Najviše trgovačkih poslova odvijalo se tokom avgusta, te su u tom periodu trgovci imali najviše uspeha u prodaji.

13 Ovaj internacional frazem proistekao je iz različitih narodnih priča (npr. Seoski miš i gradski miš), a pozadinsku sliku čini i skroman siromašan život u crkvi.

14 U francuskom i španskom jeziku umesto lekseme dlaka upotrebljava se perje.
} 
srp. biti go kao pištolj / fr. - / šp. -

srp. nema pas za šta da ga ujede / fr. - / šp. -

srp. go kao crkveni miš / fr. - / šp. -

srp. ostati bez gaća / fr. - / šp. -

srp. - / fr. être nu comme un ver ('biti go kao crv') / šp. -

srp. - / fr. être pauvre comme Job ('biti siromašan kao Jov') / šp. -

srp. - / fr. - / šp. estar, quedarse a dos velas ${ }^{15}$ ('biti, postati dve sveće')

srp. - / fr. - / šp. ser un muerto de hambre ('biti mrtav od gladi')

Ovde pronalazimo i frazeme koji za razliku od prethodno navedenih ne ukazuju obavezno na siromaštvo, nego na trenutnu besparicu:

srp. biti kratak s novcem / fr. être à court d'argent / šp. estar corto de dinero srp. potrošiti do poslednje pare / fr. dépenser jusqu'au dernier sou / šp. gastar hasta el último centavo

srp. dati zadnji dinar / fr. - / šp. dar el último centavo

srp. - / fr. être à sec ('biti na suvom') / šp. quedarse en seco ('biti na suvom') srp. - / fr. avoir la bourse vide ('imati praznu kesu') / šp. tener un bolsillo vacio ('imati praznu kesu')

srp. isprazniti kesu / fr. - / šp. -

srp. isprazniti, izvrnuti džepove / fr. - / šp. -

srp. nema ni žute banke / fr. - / šp. -

srp. - / fr. avoir le gousset vide ('imati prazan džep na prsluku') / šp. -

srp. - / fr. être fauché comme les blés ('biti pokošen kao žito') / šp. -

srp. - / fr. n'avoir pas un radis ('nemati rotkvicu') / šp. -

srp. - / fr. avoir le diable dans sa bourse ('imati đavola u torbi') / šp. -

srp. - / fr. - / šp. no tener ni una blanca ('nemati ni bele')

srp. - / fr. - / šp. no tener ni, quedarse sin gorda ('nemati ni, ostati bez debele')

srp. - / fr. - / šp. estar, quedarse a (en) la cuarta pregunta' ('biti, ostati na četvrtom pitanju')

Pojedini frazemi sadrže naziv današnje ili nekadašnje novčane jedinice i takođe prevashodno upućuju na trenutno neimanje novca:

srp. - / fr. n'avoir pas un centime ('nemati centima') / šp. no tener un solo centavo ('nemati nijednog samog centima')

srp. nema ni prebijene pare, prebijenog dinara / fr. - / šp. -

srp. - / fr. n'avoir pas un écu ('nemati talira') / šp. -

srp. - / fr. n'avoir pas un sou vaillant ('nemati vrednog sua') / šp. -

\footnotetext{
15 Nekada su kartaroške igre bile nezakonite i odvijale su se u mračnim prostorijama. Igrač koji je pobeđivao kraj sebe je imao dve sveće kako bi mogao da izbroji dobitak. Onome koji izgubi ostajale bi samo dve sveće.

16 U Španiji je nekada bio običaj da pisar na suđenjima uzima izjave putem formulara sa četiri pitanja: 1) ime i godište, 2) zemlja rođenja i zanimanje, 3) veroispovest i bračno stanje, 4) imovinsko stanje. Na četvrto pitanje svi su davali odričan odgovor kako ne bi morali da plaćaju velike kazne.
} 
2) Konceptualno polje ‘čovekov odnos prema novcu’

U ovo konceptualno polje svrstale smo frazeme koji upućujući na čovekov odnos prema novcu zapravo otkrivaju šarenolike karakterne osobine. Prema pozadinskoj slici koja ih boji, frazeme smo svrstale u dve grupe. Prvu čine oni koji ukazuju na dobre čovekove osobine, a drugu oni koji otkrivaju nepoželjne osobine:

a) poželjne osobine:

'velikodušnost':

srp. biti široke ruke / fr. - / šp. a manos llenas

srp. deliti kapom i šakom ${ }^{17} /$ fr. - / šp. -

srp. - / fr. - / šp. ser un tío de bigote ('biti čika s brkovima')

'štedljivost':

srp. stavljati (novac) sa strane / fr. mettre de l'argent de côté / šp. srp. držati, čuvati pare u slamarici / fr. - / šp. guardar el dinero bajo el colchón srp. držati, čuvati novac u čarapi / fr. - / šp. guardar dinero en un calcetín srp. čuvati (bele novce) za crne dane / fr. - / šp. srp. paru na paru stavljati / fr. - / šp. -

srp. - / fr. garder une poire pour la soif (‘čuvati krušku za žeđ’) / šp. srp. - / fr. mettre à gauche ('stavljati levo') / šp. srp. - / fr. - / šp. almacenar dinero ('skladištiti novac')

a) nepoželjne osobine:

'rasipništvo', 'nerazumno i uzaludno trošenje novca':

srp. novac mu curi kroz prste / fr. l'argent lui coule des doigts / šp. el dinero se le escurre entre los dedos

srp. bacati novac, pare kroz prozor ${ }^{18}$ / fr. jeter l'argent par les fenêtres / šp. tirar el dinero por la ventana

srp. propiti novac / fr. boire son argent / šp. dinero bebido

srp. - / fr. jeter l'argent à pleines mains ('bacati novac punim rukama') / šp. tirar el dinero a manos llenas ('bacati novac punim rukama')

srp. - / fr. dévorer, engloutir de l'argent ('proždirati novac') / šp. devorar, engullir el dinero ('proždirati novac')

srp. - / fr. semer son argent ('sejati svoj novac') / šp. sembrar dinero ('sejati novac')

srp. bacati novac u vodu / fr. - / šp. -

Posmatrani frazem ima šire značenje, kapom $i$ šakom može da se deli i posao, hrana i slično.

18 Frazem je internacionalan i potiče iz Lafontenove basne u kojoj majmun kroz prozor baca novac bogatog, a škrtog čoveka. 
srp. - / fr. croquer son argent ('grickati svoj novac') / šp. -

srp. - / fr. manger de l'argent ('jesti novac') / šp. -

srp. - / fr. être un panier percé ('biti probušena korpa') / šp. -

srp. - / fr. manger la grenouille ${ }^{19}$ ('pojesti žabu') / šp. -

srp. - / fr. un (vrai) bourreau d'argent ('(pravi) dželat novca') / šp. -

srp. - / fr. faire valser l'argent ('činiti da novac pleše') / šp. -

srp. - / fr. faire la tournée des grands ducs ('praviti turneju kneževa') $)^{20} /$ šp. -

Srpski frazem svrbe, žuljaju ga pare ne iskazuje obavezno uzaludno trošenje novca, mada upućuje na čoveka koji ne može da sačuva novac duže vreme i teško se suzdržava u trošenju:

'tvrdičluk':

srp. imati zmiju u džepu, novčaniku / fr. avoir des oursins dans la poche, le porte-monnaie ('imati morske ježeve u džepu, novčaniku') / šp. tener cocodrilos en el bolsillo ('imati krokodile u džepu') ${ }^{21}$

srp. drhtati nad svakim dinarom / fr. - / šp. temblar por cada céntimo

srp. biti tvrd na novcu / fr. - / šp. -

srp. stegnuti, stisnuti, zavezati kesu / fr. - / šp. -

srp. - / fr. - / šp. estrujar el dinero ('cediti novac')

srp. - / fr. - / šp. morir por un bledo ('umirati zbog jedne blitve')

srp. - / fr. - / šp. rascarse el bolsillo ('češati se po džepu')

srp. - / fr. - / šp. bolsa de hierro ('gvozdena kesa')

'proračunatost':

srp. raditi za svoj groš / fr. - / šp. trabajar por su cuenta

srp. gleda sve kroz dinar / fr. - / šp. -

\section{3) Konceptualno polje 'novčana vrednost stvari'}

Frazeme u ovoj grupi razvrstale smo u četiri podgrupe zavisno od toga da li izražavaju malu, veliku ili neprocenjivu vrednost nekog predmeta, odnosno da li upućuju na nešto za šta nije potrebno ulaganje novca:

a) 'bezvredne stvari':

srp. ne vredi ni pišljiva boba / fr. - / šp. no vale un bledo ('ne vredi ni blitvu') srp. ne vredi ni prebijene pare / fr. - / šp. -

19 Ovaj frazem datira iz sedamnaestog veka kada su kasice za štednju bile u obliku žabe. Alen Rej, međutim, smatra da poreklo ovog frazema nije tako očigledno. Po njemu, leksema 'grenouille' dolazi od žargonskog glagola 'grenouiller' koji je do devetnaestog veka imao dva značenja: 'praviti gozbe i piti u kabareima' i 'trošiti novac zarađen na loš način'.

20 U pozadinskoj slici frazema pronalazimo ruske kneževe s kraja devetnaestog i početka dvadesetog veka koji su putovali u francusku prestonicu i nemilice trošili novac na zabavu.

${ }^{21}$ Iako se u tri jezika pominju nazivi različitih životinja, budući da su u pitanju opasne životinje, frazeme navodimo kao istovetne. 
b) 'mala novčana vrednost stvari': dólares

srp. za šaku dolara / fr. pour une poignée de dollars / šp. por un puñado de srp. za svačiji džep / fr. - / šp. para cada bolsillo

srp. - / fr. - / šp. costar a precio de huevo ('koštati po ceni jajeta')

c) 'velika novčana vrednost stvari': de la cara

srp. košta kao oči u glavi / fr. cela coûte les yeux de la tête / šp. cuesta un ojo srp. dati masne, lepe, dobre pare za nešto / fr. - / šp. -

srp. platiti papreno / fr. - / šp. -

srp. košta đavo i po / fr. - / šp. -

srp. košta kao svetog Petra kajgana / fr. - / šp. -

srp. - / fr. cela coûte un bras ('to košta jednu ruku') / šp. -

srp. - / fr. - / šp. costar a pelos de demonio ('koštati kao đavolja dlaka')

srp. - / fr. - / šp. costar un riñón ('koštati kao bubreg')

srp. - / fr. - / šp. caro como aceite de Aparicio 22 ('skup kao Aparisijevo ulje')

srp. - / fr. - / šp. estar por las nubes ('biti do oblaka')

d) 'neprocenjiva vrednost stvari koja se novcem ne može kupiti':

srp. - / fr. pour tout l'or du monde (u odričnoj rečenici) ('za sve zlato sveta') / šp. ni por todo el oro del mundo ('ni za sve zlato sveta')

srp. ni za koje novce, pare / fr. - / šp. -

srp. nema tih para koji koga, nešto mogu da plate / fr. - / šp. -

e) 'besplatne usluge':

srp. - / fr. ça ne mange pas de pain ('to ne jede hleba') / šp. eso no come pan ('to ne jede hleba')

srp. - / fr. aux frais de la princesse ('na princezin račun') / šp. -

srp. - / fr. - / šp. de balde ('od kabla')

srp. - / fr. - / šp. de gorra ('od kape')

4) U ovu grupu uvrstile smo frazeme koji se odnose na finansijsku samostalnost, izlaganje druge osobe velikom trošku i nezakonito sticanje novca:

a) 'finansijska nezavisnost':

srp. dati, platiti iz svog džepa / fr. donner, payer de sa poche / šp. pagar de su bolsillo

srp. imati svoju kesu u svom džepu / fr. - / šp. -

b) 'izložiti nekoga velikom trošku':

$\overline{22}$ Ovo veoma skupo lekovito ulje u šesnaestom veku napravio je Aparisio iz Subje za vidanje čireva i rana. 
srp. udariti koga po džepu / fr. - / šp. dar un cabe al bolsillo srp. zaviriti u nečiji džep / fr. - / šp. -

srp. isterati, izbiti paru nekome iz džepa / fr. - / šp. -

c) 'nezakonito sticanje novca':

srp. Judina para $^{23}$ / fr. - / šp. -

srp. - / fr. argent gris ${ }^{24}$ ('sivi novac') / šp. -

5) Semantika pojedinih frazema u našem korpusu ne upućuje na novac, uprkos komponentama koje pripadaju ovom semantičkom polju. Ovi frazemi izražavaju neku čovekovu karakternu osobinu ili vrednost stvari:

'pohlepa':

srp. želeti i jare i pare / fr. - / šp. -

srp. želeti i ovce i novce / fr. - / šp. -

srp. - / fr. vouloir le beurre et l'argent du beurre ('želeti puter i novac od putera') / šp. -

srp. - / fr. vouloir avoir, garder le drap et l'argent ${ }^{25}$ ('želeti i čaršav i novac') / šp. -

'dragocenost osobe ili predmeta':

srp. vredeti carstvo / fr. - / šp. valer un imperio

srp. blaga vredi / fr. - / šp. vale un tesoro

srp. - / fr. il vaut son pesant d'or ('vredi zlata koliko je težak') / šp. vale su peso en oro ('vredi zlata koliko je težak')

srp. vredi zlata / fr. - / šp. -

'uzvratiti istom merom':

srp. - / fr. rendre à quelqu'un la monnaie de sa pièce ('vratiti nekome kusur njegovim novcem') / šp. devolver con la misma moneda ('vratiti istom valutom') 'pritajiti se', 'biti nezapažen':

srp. stisnuti se kao dve pare u kesi / fr. - / šp. -

'uzeti zdravo za gotovo':

srp. - / fr. prendre quelque chose pour argent comptant ('uzeti nešto kao gotov novac') / šp. -

'dobro poznavati nekoga' (sa negativnom konotacijom):

srp. znati nekoga kao zlu paru / fr. - / šp. -

'veoma čist':

srp. - / fr. propre comme un sou (neuf) ('čist kao novčić (nov)’) / šp. limpio como una patena, más limpio que una patena ('čist kao dukat')

Novac primljen za izdajnički posao, mito.

Naziv za novac stečen prevashodno prevarom i utajom poreza.

Pozadinsku sliku frazema pronalazimo u Farsi o Patlenu koji odnosi čaršav ne plativši ga. 


\section{ZAKLJUČAK}

Spojem pojmovnih metafora i konceptualnih polja dobile smo slojevitu i šaroliku sliku o pojmu novca. Istraživanje pokazuje da su frazemi sa komponentom srp. novac, pare / fr. argent / šp. dinero i semantički bliskim leksemama brojni u tri posmatrane lingvokulturalne zajednice i to u svakodnevnom razgovornom jeziku, te da se konceptualno polje 'novac' prepliće sa konceptualnim poljima 'bogatstvo' i 'siromaštvo'. Definisale smo pet grupa i utvrdile da frazemi u našem korpusu prevashodno oslikavaju posedovanje velike količine novca, trenutnu besparicu i nerazumno i uzaludno trošenje.

Zanimljivo je istaći da se, uprkos brojčanoj ujednačenosti frazema, u srpskom, francuskom i španskom jeziku novac ne poima istovetno. To potvrđuju i dobijeni rezultati, budući da se od 169 frazema leksičko i semantičko poklapanje u tri jezika pojavljuje u svega 24 primera, a u dva jezika u 30 primera (srpski/francuski - 3, srpski/španski - 13, francuski/španski - 14). Najbrojniji su frazemi koji postoje samo u jednom jeziku: srpski - 49, francuski - 36, španski - 30 .

Kod većine posmatranih frazema pozadinska slika je lako uočljiva i razumljiva. Pojedini frazemi, međutim, iziskivali su dublje tumačenje budući da su obojeni mitologijom, religijom, istorijom, društvenim i tradicionalnim okolnostima triju posmatranih zajednica.

Ksenija Šulović

Dragana Drobnjak

\section{MONEY IN SERBIAN, FRENCH AND SPANISH PHRASEOLOGY}

\section{SUMMARY}

Combining conceptual metaphor and field, we have got layered and colorful image about perception of money in Serbian, French and Spanish.

The main aim of this research is to show that the phraseological units with component $\mathrm{Sr}$. novac ('money') / Fr. argent / Sp. Dinero and semantically similar lexemes are numerous in three languages and in colloquial language. The semantic field of 'money' is intertwined with semantic fields of 'wealth' and 'poverty'. We defined five groups and determined that expressions in our corpus primarily reflect possession of large amounts of money, current shortage of money and irrational waste of money.

Despite the numerical consistency of phrasemes, money is not perceived identically in Serbian, French and Spanish. As it was confirmed by the results in 169 idioms, formal and semantic overlapping in the three languages appears in only 24 cases, in two languages in 30 cases (Serbian/French -3, Serbian/Spanish -13, French/Spanish - 14). The most numerous are the expressions that exist in only one language: Serbian -49 , French -36 and Spanish -30 .

Key words: money, phraseme, Serban, French, Spanish. 


\section{LITERATURA}

Buitrago, A. (2000). Diccionario de dichos y frases hechas. Madrid: Editorial Espasa Calpe, S.A.

Burger, H., Buhofer, A., Sialm, A. (1982). Handbuch der Phraseologie. Berlin/ New York: Walter de Gruyter.

Burger, H. (2003). Phraseologie. Eine Einführung am Beispiel des Deutschen. Berlin: Erich Schmidt Verlag.

Klikovac, D. (2000). Semantika predloga. Beograd: Filološki fakultet.

Kövecses, Z. (2002). Metaphor. A Practical Introduction. New York: Oxford University Press.

Zybatow, L. (1997). Idiome und Parömien aus kognitivlinguistischer und translationslinguistischer Sicht (am Beispiel des Russischen und Ukrainischen). U: Internationale Tendenzen der Syntaktik, Semantik und Pragmatik. Akten des 32. Linguistischen Kolloquiums in Kassel 1997 (Hrsg. O. Spillmann / I. Warnke), Peter Lang - Europäischer Verlag der Wissenschaften, str. 579-588.

Драгићевић, Р. (2010). Вербалне асоиијаџије кроз срӣски језик и кулйуру. Београд: Друштво за српски језик и књижевност Србије.

Шуловић, К., Дробњак, Д. (2015). Појам новца у српском, француском и шпанском језику. Зборник Майице срӣске за филолойју и линівистиику, LVIII/1, 197-207.

Clave Diccionario de uso del español actual (2002). Madrid: Ediciones SM.

Diccionario de la lengua española (1992). Madrid: Real Academia Española.

Drašković, V. (1990). Francusko-srpskohrvatski frazeološki rečnik. Beograd: Zavod za udžbenike i nastavna sredstva.

Le nouveau Petit Robert, Dictionnaire alphabétique et analogique de la langue française (2005). Paris: Robert.

Milosavljević, B. (1994). Srpsko-francuski rečnik idioma i izreka. Beograd: Srpska književna zadruga.

Rey, A. (2000). Le Robert, Dictionnaire historique de la langue française. Paris : Dictionnaire Le Robert.

RMS 1. РMC 1: Речник срӣскоїа језика (2007). Нови Сад: Матица српска.

RMS 6. РMC 6: Речник срйскохрвайскоїа књижевної језика I-VI (1967-1976). Нови Сад (- Загреб): Матица српска (- Матица хрватска).

Sanmartín Sáez, J. (2002). Diccionario de argot. Madrid: Editorial Espasa Calpe, S. A.

Seco, M., Andrés, O., Ramos, G., (2009). Diccionario fraseológico documentado del español actual: locuciones y modismos españoles. Madrid: Aguilar.

Trésor de la langue française : dictionnaire de la langue du XIX et du XX siècle (1971-1994). Paris, Éd. du Centre national de la recherche scientifique: Klincksieck: Gallimard. 